\title{
Managing supply chain knowledge-based linkages for improving operational performance
}

\author{
Marianna Marra \\ Operations and Information Management Group \\ Aston Business School, Aston University, Birmingham B4 7ET, UK
}

\author{
William Ho* \\ Department of Management and Marketing
}

The University of Melbourne, 198 Berkeley Street, Carlton, Victoria 3010, Australia

\author{
Carman Ka Man Lee
}

Department of Industrial and Systems Engineering, The Hong Kong Polytechnic University, Hung Hom, Kowloon, Hong Kong

\begin{abstract}
Purpose - This paper aims to explore the role of internal and external knowledge-based linkages across the supply chain in achieving better operational performance. It investigates how knowledge is accumulated, shared, and applied to create organization specific knowledge resources that increase and sustain the organization's competitive advantage.
\end{abstract}

Design/methodology/approach - This paper uses a single case study with multiple, embedded units of analysis, and the social network analysis (SNA) to demonstrate the impact of internal and external knowledge-based linkages across multiple tiers in the supply chain on the organizations' operational performance. The focal company of the case study is an Italian manufacturer supplying rubber components to European automotive enterprises.

Findings - With the aid of the SNA, the internal knowledge-based linkages were mapped and visualized. We found that the most central nodes having the most connections with other nodes in the linkages are the most crucial members in terms of knowledge exploration and exploitation within the organization. We also revealed that the effective management of external knowledgebased linkages, such as buyer, competitors, university, suppliers, and subcontractors, can help improve the operational performance. 
Research limitations/implications - First, our hypothesis was tested on a single case. The analysis of multiple case studies using SNA would provide a deeper understanding of the relationship between the knowledge-based linkages at all levels of the supply chain and the integration of knowledge. Second, the static nature of knowledge flows was studied in this research. Future research could also consider on-going monitoring of dynamic linkages and the dynamic characteristic of knowledge flows.

Originality/value - To the best of our knowledge, the phrase "knowledge-based linkages" has not been used in the literature and there is lack of investigation on the relationship between the management of internal and external knowledge-based linkages and the operational performance. To bridge the knowledge gap, this paper will show the importance of understanding the composition and characteristics of knowledge-based linkages and their knowledge nodes. In addition, this paper will show that effective management of knowledge-based linkages leads to the creation of new knowledge and improves organizations’ operational performance.

Keywords Supply chain management, Knowledge-based linkages, Operational performance, Social network analysis, Case study

Paper type Case study

*Corresponding author. 


\section{Introduction}

Recently, there is a growing interest in studying and managing flows of knowledge in contemporary knowledge-intensive supply chains (Hult et al., 2004, 2006; Gunasekaran and Ngai, 2007; Ketchen and Hult, 2007; Ketchen, et al., 2008). A crucial problem is to find key knowledge assets in these supply chains and to exploit the knowledge in an efficient manner (Desouza et al., 2003). These contributions suggest that sustainable competitive advantage is associated with the effective management of complex knowledge flows. Building on these studies, this paper aims to identify the role of internal and external knowledge-based linkages in improving the operational performance of the organizations through better exploration and exploitation of individual and organizational knowledge (Polanyi, 1962; Tsoukas and Vladimirou, 2002).

We define knowledge-based linkages as implicit and explicit connections that are characterized by high levels of tacit knowledge, are influenced by and embedded in human relationships, and are characterized by informal socialization mechanisms (Lawson et al., 2009; Carey and Lawson, 2011). Every organization should be seen as a linkage in the chain between suppliers and consumers. All linkages are connected through open collaboration to foster learning and developing new knowledge (Flynn et al., 1994; Hackman and Wageman, 1995). Along these linkages, we consider learning to be an activity triggered by the gap between potential and effective performance (Von Hippel and Tyre, 1995), and generated by people’s social interactions and the activities in which people engage (Nonaka, 1994). In line with Burns and Stalker (1966) and Hurley and Hult (1998), we consider that a firm with a successful learning process has a stronger capability to innovate in products and processes.

While the positive role of internal knowledge transfer is widely recognized, the reinforcing relationship between internal and external knowledge transfer and their intertwined nature has not received adequate attention. In this study, the focus is confined to the process of knowledge sharing and development, and the role of effective management of knowledge-based linkages in improving quality, and ultimately, increasing firms' operational performance. We expect that sustainable competitive advantage is dependent on effective management of the knowledgebased linkages along the supply chain, and show that the reinforcing relationship between external and internal knowledge transfer, and its intertwined nature, allow individuals to integrate their knowledge in the form of capabilities. In line with the knowledge-based view (KBV), these capabilities are seen as explanatory variables for performance (Grant, 1996).

We investigate two main research questions. First, how do organizations create new knowledge along their internal and external linkages? Second, what is the impact of managing 
the knowledge-based linkages on the operational performance? To address the answers, we use the social network analysis (hereafter SNA) to map the knowledge-based linkages and visualize the knowledge exploration and exploitation along the linkages of a case company. The SNA tools provide scholars and practitioners with a better understanding of the most knowledgeable individuals, who are expected to embody the most important knowledge and to be responsible for new knowledge creation.

\section{Literature review}

In the area of supply chain management, effective transfer of tacit and explicit knowledge can help create new products and services, and improve the quality of existing products. First, knowledge integration is important for successful new product development (Clark, 1989). The reason why organizations integrate different sources of knowledge is to access resources that are not available internally, and to enable outsourcing of research and development (R\&D) or new product development activities to business partners along the supply chain (Andersson et al., 2002). Second, the role of knowledge for improving quality and quality management practices has been widely recognized (Linderman et al., 2004; Choo et al., 2007; Molina et al., 2007; Anand et al., 2010), and quality improvement activities are seen as related strictly to learning and knowledge creation (Osterloh and Frey, 2000).

The synergies between supply chain and knowledge management are highlighted in Desouza et al. (2003). They point out that: a) connectivity allows the flow of knowledge throughout the supply chain; b) communication of supply chain knowledge allows faster decision making; c) ability to collaborate in real time fosters knowledge sharing and adjustment to changes in the market place. Thus, the capability to effectively transfer knowledge from one unit to another is acknowledged to a prime source of organizational competitive advantage, but is also considered very difficult to achieve (Hamel, 1991; Grant, 1996; Argote et al., 2000; Amin and Cohendet, 2005). Along this line of researches, a growing attention has focused on the learning aspect of collaboration along the supply chain and on the obstacles to knowledge creation (Bessant et al. 2003; Bessant, 2004; Wadhwa and Saxena, 2005; Cheung et al. 2010; Samuel et al. 2011), such as the tacit characteristic of knowledge and how it affects the knowledge sharing process along the supply chain (Wagner and Bukò, 2005). Specific knowledge elements have been highlighted as crucial for the supply chain performance, such as memory, tacitness, accessibility, quality, use, intensity, responsiveness, and learning capacity (Hult et al., 2006). Ketchen and Hult (2007) and Ketchen et al. (2008) describe the characteristics of contemporary global supply chains where the focus is on developing best value, 
high quality, and customer satisfaction. Other studies have also suggested that knowledge management tools can be employed by contemporary supply chains to enhance productivity and quality (Gunasekaran and Nagai, 2007; Modi and Mabert, 2007). Recently, Ding et al. (2012) analyze two strategies for internal knowledge transfer, codification and rich media strategy, and investigate the relationship between these strategies and knowledge spillovers. Lee et al. (2013) provide evidence that knowledge management practices have a positive influence on technological innovation.

Despite knowledge is widely recognized in the above mentioned researches as a valuable resource for the supply chain competitive advantage, few studies examine specifically how knowledge is accumulated, shared, and applied within the supply chain, especially pointing to the specific role of individuals within the knowledge-based linkages. To the best of our knowledge, the phrase "knowledge-based linkages" has not been used in the literature and there is lack of investigation on the relationship between the management of internal and external knowledge-based linkages and the operational performance. To bridge the knowledge gap, this paper will show the importance of understanding the composition and characteristics of knowledge-based linkages and their knowledge nodes. In addition, this paper will show that effective management of knowledge-based linkages leads to the creation of new knowledge and improvement of organizations’ operational performance.

\section{Methods}

The context of knowledge-based linkages is a complex social phenomenon involving multiple players. Also, the open-ended nature of our research questions suggests a qualitative approach as the most appropriate method. Our approach is based on data gathered through an in-depth case study, combined with the insights provided by the SNA. This combination is appropriate for analyzing knowledge exploration and exploitation along the internal and external linkages.

$<$ Insert Figure 1 about here $>$

Figure 1 shows the flow chart of the research methodology. To select the case, we adopted a theoretical sampling approach (Eisenhardt and Graebner, 2007). First, we selected the automotive industry, which is regarded as one of the most complex industries in terms of the technologies and players involved in the production process (Maxton and Wormald, 2004). Second, we selected a manufacturing company supplying rubber components to the automotive industry as the case company (hereafter ALPHA).

After selecting the case company, we arranged a meeting with the senior management. We conducted a first round of interviews to collect information about the company. We also 
collected company publications and documentation about the company's history. Thus, our data sources included company documentation, direct observations, and interviews. This allowed triangulation of data from different sources (Eisenhardt, 1989; Choi and Hong, 2002), and enabled identification of a particular group of interest within the company, which is the Quality Assurance Group.

SNA is a methodology that allows mapping of knowledge-based linkages; its main potential is its capacity to visualize relationships, and to monitor information and knowledge flows (Cross and Parker, 2004). According to Pryke (2004), SNA is "a set of tools for mapping important knowledge relationship between people or departments”. According to this approach, the main goals of social research are "to trace vertical and lateral information flows, identify sources and goals” (Garton et al., 1997), to improve knowledge flows, identify missing connections, and understand the nature of social ties and the degree of their intensity (Kilduff and Tsai, 2003). There are two main approaches to study a network or linkage: egocentric and bounded (Cross and Parker, 2004). An egocentric approach involves the collection of data from one individual who identifies the other people who are important. The purpose is to identify the most central node in the informal network, or the group team leader. According to Cross and Parker (2004), the main advantage of egocentric network analysis is that it can uncover all the important relationships of the focal individual. The most used method is a survey. A bounded network approach involves the identification of a network of interest, which might be a division (the R\&D group or the Quality Control Department). In this case, the researcher surveyed every group member to obtain details on their relationships with the other members of the group. We opted for a bounded approach based on the characteristics of ALPHA and the identified Quality Assurance Group. Our choice was influenced by the introduction of total quality management (TQM) in ALPHA, which had affected the company’s operational performance.

Our hypothesis in relation to the research questions is that if crucial knowledge is developed through ties, then the nodes with more ties (greater degree centrality) will have more information and knowledge, and to the extent that information and knowledge have an impact on areas such as quality, will demonstrate better operational performance.

We studied the centrality attributes of our nodes. In SNA, central people are likely to be the most influential and the most likely to be able to communicate options with others (Friedkin, 1993). We regard centrality as a measure of power and influence since a greater number of connections is likely to endow importance in the network. The literature uses various measures for centrality. In this study, we considered the following measures:

- According to Freeman (1979), degree centrality can be measured as: 


$$
C_{D}=\frac{\sum_{1=l}^{g}\left[C_{D}\left(n^{*}\right)-C_{D}\left(n_{i}\right)\right]}{[(g-1)(g-2)]}
$$

We distinguish also between in-degree and out-degree centrality. The former is the number of incoming ties a person has for a given relationship, the latter is the number of outgoing ties a person has for a given relationship.

- Betweenness shows the extent to which a particular node lies between the others in the network and can be defined as:

$$
b(i)=\sum_{j k} \frac{g_{j k k}}{g_{j k}}
$$

where $g j k$ is the number of the shortest paths between node $j$ and node $k(j, k \neq i)$ that pass through node $i$.

- Eigenvector centrality is used to find the most central actors in terms of the "global" or "overall” structure of the network. It is defined as:

$$
\lambda v=A v
$$

where $A$ is the adjacency matrix of the graph, lambda is a constant (the eigenvalue), and $v$ is the eigenvector.

We aimed first to administer the SNA questionnaire to the Quality Assurance Group in order to map the internal knowledge-based linkages across the group. The questionnaire was developed following Cross and Parker's (2004) work on conducting and interpreting SNA. It was designed to be free call ${ }^{1}$. Then, the questionnaire was followed-up by email exchanges with respondents. The data collected via the survey were analyzed using the UCINET software packages and allowed us to map the organization's internal knowledge based linkages and identify the most central nodes of the linkage. The results were shared with the organization's top management and in-depth interviews were conducted with the most central (knowledge accumulating) nodes to understand their role in cultivating, nurturing, managing, and driving the management of knowledge-based links. The external knowledge-based linkages of the organization were mapped and the learning outputs were identified.

\section{Within-case analysis}

\footnotetext{
${ }^{1}$ There are two main strategies that can be adopted when designing a SNA questionnaire: a recognition model, which provides respondents with a list of names; and free call, where respondents are required to nominate actors.
} 
In this section, we present the within case analysis of the company's internal and external knowledge-based linkages. The object of our analysis is a manufacturing company, ALPHA, which is a supplier of rubber car components to a major Italian auto manufacturer. The company is situated in Italy, and was founded in 1972. Over the past 40 years, the company has been affected by some strategic decisions. In 1982, its fundamental product sector became the profiles for automotive and industrial application, and in 1985, it started R\&D activity. It also produced for foreign markets between 1990 and 1992. During the period of our analysis, it has 300 employees.

\section{$<$ Insert Figure 2 about here $>$}

The company has to manage three major complex quality problems:

- The specificity of the material (rubber) - There are several technical problems. High temperatures are required, which make the material fragile and easily deformable. The makeup of the rubber is complicated, and requires the right measure of viscosity. The expected exact shape of the final components is strongly affected by the high temperatures in the extrusion line (Figure 2, points 4-5);

- Size of final component - Because of the above reasons, achieving accurately sized output is difficult. The company produces semi-finished products to be assembled into the final product by the buyer - the automobile manufacturer. To precisely adhere to the measures required by the buyer, the margin of error in the measurement of the final component is very small;

- Process - The production process needs to be standardized in order to reduce errors in the extrusion line.

\subsection{Internal knowledge-based linkages}

According to the hypothesis, the most central nodes in the knowledge-based linkages are the knowledge accumulating nodes. The knowledge accumulating nodes are the most knowledgeable people in the organization, the key employees who determine the development of organization-specific knowledge, who embody important knowledge, and who contribute to the development of new knowledge. If the goal is to create new knowledge and to exchange existing knowledge, we need to focus on the most knowledgeable individuals or groups in the company.

Figure 3 depicts the internal knowledge transfer among the members of the Quality Assurance Group and the members of other groups they identified. Among these, $\mathrm{A}^{2}, \mathrm{~B}, \mathrm{D}, \mathrm{E}, \mathrm{F}$, G, H, and I are members of the Quality Assurance Group. The arrows on the ties between the

\footnotetext{
${ }^{2}$ For reasons of anonymity all nodes are referred to by randomly chosen letters of the alphabet.
} 
nodes show the direction of their nomination. Reciprocal nominations are indicated by a twoway arrow.

The map of the internal knowledge-based linkages (Figures 3 to 6) and the centrality measures of its nodes (Tables 1 to 4 ) show that:

- The knowledge transfer structure relies on collaboration between the Quality Assurance Group (nodes A, B, D, E, F, G, H, and I), the R\&D (node C), the Extrusions and Finishing Department (node L), and the CEO (node M), which are connected by the corresponding knowledge-based linkages.

- Figure 4, Table 1, and Table 2 show the findings obtained from the Freeman's degree centrality measures. Five nodes have the highest value and therefore are regarded as the most central. The output reports the in-degree and out-degree values. A number of important observations can be argued. Node L shows the biggest shape with a corresponding value of in-degree centrality equals to 9.000, and out-degree equals to 1.000. This means that it obtained the highest number of choices by the others members that consider this node as the most influential for the quality improvements of the company. He is also the person to which the others refer to in order to solve a problem in their daily work activity. Node B is the second to receive the highest number of choices (in-degree $=5.000$, out-degree $=1.000$ ). Then, Node A shows in-degree $=2.000$ and out-degree=2.000; Node $\mathrm{M}$ has in-degree=3.000 and out-degree= 3.000; Node D indegree $=2.000$ and out-degree $=4.000$. We define these individuals as the most knowledgeable nodes. They absorb and embody the knowledge and competences that allow them to generate new knowledge applicable to the company's main quality problems. They have the greatest influence over the organization's internal and external knowledge-based linkages. Figure 4 shows also the resulting clique, where the five most central nodes are represented by bigger shapes, the nodes that received the highest number of nominations are the biggest ones based on the number of their ties.

$$
\begin{aligned}
& <\text { Insert Figure } 3 \text { about here }> \\
& <\text { Insert Figure } 4 \text { about here }> \\
& <\text { Insert Figure } 5 \text { about here> } \\
& <\text { Insert Figure } 6 \text { about here> } \\
& <\text { Insert Table } 1 \text { about here> } \\
& <\text { Insert Table } 2 \text { about here> } \\
& <\text { Insert Table } 3 \text { about here> } \\
& <\text { Insert Table } 4 \text { about here> }
\end{aligned}
$$


The role of each member is described as follows, and is summarized in Table 5.

- Node $\mathrm{L}$ is the most central and most influential node, with the greatest access to information and knowledge. He was not a member of the Quality Assurance Group during the period of our analysis, but was important for the knowledge transfer process both within the organization and with the external environment. Currently, he is the director of Extrusion and Finishing Department. Node L was identified as the most important person in relation to the quality improvement processes undertaken by the organization over the years and as the most useful for problem solving. He is regarded as a knowledge broker. He introduced a system of benchmarking against competitors and was responsible, together with Node B, for the TQM programme in ALPHA. The two nodes ( $\mathrm{L}$ and $\mathrm{B}$ ), in fact, show a reciprocal tie, they mentioned each other. He is also a bridge between ALPHA and its competitors, suppliers, and subcontractors. These relationships will be discussed later.

- Nodes C (Director of R\&D Department) and M (CEO of ALPHA) are also not members of the Quality Assurance Group. It is worth nothing that Node C shows a value of outdegree equals to 3.000 but no in-degree value. This shows that the R\&D Department relies strongly on the input received from the Quality Assurance Group and the Extrusion and Finishing Department.

- Node M is the CEO. If top management agrees with and supports the strategic decisions of others within the company, their implementation is more likely to be successful and to have an impact on operational performance. He acts as a bridge between ALPHA and a university research centre where he has personal contacts. In fact, it is worth noting that it shows a reciprocal tie with Node D.

- Node D acts as a gatekeeper between AlPHA and an important external partner, the university research centre, with which he collaborated to develop a software tool to monitor the extrusion line process. At the time of our research, D was recently recruited to the company from the university research centre. He had collaborated on the development of the software and subsequently took up full time employment in ALPHA.

- Node B is the director of the Quality Assurance Group. Together with Node L, he was responsible for the introduction and implementation of the TQM programme within the company. He acts as a bridge between ALPHA and its suppliers, in collaboration with node L.

- Node A is one of the Quality Managers of the group.

$<$ Insert Table 5 about here $>$ 


\subsection{External knowledge-based linkages}

We draw on the information derived from in-depth ex post interviews with the five most central nodes to explore the external knowledge-based linkages. These were identified by the most knowledgeable individuals. They are the drivers of those linkages. Figure 7 depicts the external knowledge-based linkages of AlPHA. Table 6 presents the related role and main learning outcome of each of these linkages and the implications on the operational performance.

$<$ Insert Figure 7 about here $>$

$<$ Insert Table 6 about here $>$

\subsubsection{ALPHA - buyer company}

The traditional buyer-supplier relationship is affected by the changing demands of the buyer. Nowadays, the buyer has changed radically and demanded higher quality from ALPHA. For example, in 1994, the parts per million (PPM) of error accepted by the buyer was 5,700; in 2008 the margin was only 258. This meant that ALPHA had to radically improve the quality of its output.

The knowledge-based linkage between the two organizations allowed the sharing of information and knowledge about the level of quality expected by final customers. The information was transferred in a series of meetings between the buyer's managers and representatives of AlPHA's Quality Assurance Group. After a long learning period, ALPHA achieved stricter control of measures and parameters.

\subsubsection{ALPHA - competitors}

As a part of the continuous effort to increase quality to meet buyer's requirements, ALPHA engaged in a benchmarking against some of its competitors to understand how other companies in the same industry managed the quality issue.

The primary objective of the linkage established with one of the major European automotive manufacturers working in the luxury market segment was to conduct benchmarking activities. This allowed AlPHA to learn more about the way these companies addressed quality. It resulted in greater awareness of the importance of being lean and how to achieve it. The Quality Assurance Group began working towards the ISO 9000, common in the automotive sector, which involved a series of wider benchmarking activities. Its representatives visited factories in Europe to observe their methods, and employees went on exchanges to other organizations. As a 
result, ALPHA decided to invest in training programmes to learn about lean manufacturing and related TQM practices.

ALPHA chose Six Sigma as the means of increasing customer satisfaction, reducing the costs related to poor quality output, training employees, using inter-functional team-working, and implementing a methodology for continuous improvement to achieve world-class quality. ALPHA needed Six Sigma certification, and the CEO agreed employees engaging in the benchmarking being trained to Master Black Belt level. ${ }^{3}$ The Six Sigma methodology is designed to reduce waste and costs, and to improve the overall quality of processes and products. An interviewee told us that: "It became suddenly evident that it was not reasonable to disseminate the culture of Six Sigma at all levels of the company. It is very complicated and not intuitive”.

The Six Sigma approach requires advanced statistical capabilities and a different way of thinking about the production process. The Quality Assurance manager told us that: “As we learnt during the course, with Six Sigma the process is not more under control but it is in control (...). The main result of a Six Sigma implementation is not more output; it refers to the entire process. It changes our way of thinking the production process, because it includes the entire process not just the final product”.

At the same time, one of the main principles of a lean strategy is involvement of the whole organization in the improvement process. This was implemented following the initial Six Sigma training, in order to diffuse the culture of continuous quality improvement to all employees. This bottom-up strategy was achieved by application of Kanban and Kaizen, especially in storage and warehousing. The company achieved significant reductions in inventory levels and production costs.

We should highlight two aspects:

- Six Sigma was successful in reducing variability in the Equipment and Compounding Department and monitoring dimensions along the extrusion line. Six Sigma was introduced specifically to reduce the margins of error in the use of raw materials and to control the temperature in the mixing room, to reduce the time needed to switch between operations, and to reduce the number of errors in the extrusion line. A Six Sigma project was implemented in the mixing room, where the main problem was the viscosity of the rubber. To decrease process variability, the acceptable viscosity range was revised. This led to savings amounting to $€ 15,000$ as a result of less re-working of compounds. They achieved a $20.1 \%$ reduction in errors along the extrusion line, which

\footnotetext{
${ }^{3}$ The Six Sigma approach involves different levels of expertise: Yellow Belt is the lowest level and the progression goes through Green Belt to Black Belt and Master Black Belt - the highest level of Six Sigma expertise.
} 
combined with the time savings involved reduced production costs by a total of $€ 20,000$. A Six Sigma project was also introduced into the Design Activity but showed no major benefits. Overall, it changed the problem solving activities in the company;

- Kanban and Kaizen methods were employed to improve the production process, and involve the entire organization (all employees) by suggesting how to improve daily working activities. The main improvements were to reduce inventory levels and warehousing activities. Overall, Kanban and Kaizen methods had the biggest effects on the Finishing Department.

To summarize, the main role of the knowledge-based linkage with competitors was to share knowledge about the lean manufacturing approach and TQM practices. The main results were knowledge about the crucial role of TQM practices in developing superior value for the final customer while reducing costs, and accumulation of expertise in the application of different TQM practices by employees into different departments.

\subsubsection{ALPHA - university}

Although there had been improvements as a result of the application of TQM practices, problems still occurred and the high temperatures on the extrusion line resulted in misshapen components. To overcome the problem of misshaping, ALPHA engaged in a joint project with a university research centre to create a software tool to monitor the shape of the components during the extrusion process. The knowledge-based linkage was forged as part of an on-going partnership between the organization's Quality Assurance Group and a group of researchers working in the university.

The partnership lasted for three years, and involved regular meetings for the mutual sharing of knowledge. A long period of direct observations was required to understand the most frequent problems related to the production process, and to implement trial and error solutions. Some of the university researchers spent long periods in the company working with ALPHA's employees, which resulted in the transfer of competences and capabilities. The employees working with the researchers were selected on the basis of their competences and desire to acquire and transfer knowledge.

The output was a software tool, based on an algorithm developed by a university researcher (node D). It is the only existing system to use measures based on enhanced images. The software was patented by the company. A manager we interviewed told us that this ALPHA patent represents an organization-specific resource which is difficult to imitate. The advantages 
brought by the new tool allowed the component to be monitored throughout the production process which overcame the problems related to viscosity and high temperatures. It ensured that the component shape was maintained throughout the process through numerical elaboration of signs in real time, and fault detection.

Through this external knowledge-based linkage, sharing component specific knowledge, ALPHA achieved up to $25 \%$ reduction in waste, and improved quality of the final product significantly.

\subsubsection{ALPHA - suppliers}

The main purpose of having the knowledge-based linkage between ALPHA and its suppliers was to share knowledge about the new methods related to the quality management practices. The quality standards introduced by ALPHA meant that suppliers had to provide the right raw materials at the right time. The on-going communication and collaboration allowed suppliers to learn how to implement quality management practices and to monitor the quantity, quality, and delivery of materials. Major reductions in finished goods inventory and more accurate forecasting capability were achieved.

We should highlight two main aspects:

- The knowledge-based linkage enabled suppliers to learn from ALPHA's best practices and to implement changes. Suppliers introduced new practices (e.g., Kanban in storage and warehousing activities) learnt from knowledge sharing meetings with ALPHA, and became so-called “talented suppliers” (Smith and Tranfield, 2005).

- Suppliers were positively influenced by ALPHA's request to focus on quality, on-time and precise deliveries, resulting in increased flexibility to respond to ALPHA's requirements. This prevented ALPHA from wasting time and cost in switching suppliers, and enabled ALPHA to establish knowledge relationships with its suppliers to improve the operational performance.

\subsubsection{ALPHA - subcontractors}

The main aim of the knowledge-based linkage between these organizations was collaborative learning by doing. The subcontractors grew alongside with ALPHA, which influenced their economic development, transforming the original micro-organizations into small companies. The impact of these companies’ developments has been reciprocal. Both parties achieved reductions in inventory levels and response times. The localized learning process that affected ALPHA and its sub-contractors allowed the development of organization-specific technical resources, 
retention of tacit knowledge within the linkage and avoidance of knowledge obsolescence, and increased knowledge dispersion along the supply chain.

\section{Discussions}

5.1 How do organizations create new knowledge along their internal and external linkages?

Our case shows that the internal and external knowledge-based linkages served to achieve knowledge exploration and exploitation. Knowledge exploration and exploitation relies on the knowledge accumulating nodes in the knowledge-based linkages. This proves our hypothesis that the most central nodes having the most connections with other nodes in the linkages are the most crucial members in terms of knowledge creation and transfer. In the case study, the strategic decision of investing in TQM practices was based on those central individuals identified using SNA. They demonstrate better individual performance, and also, are responsible for the company's improved performance. They observed and learned from competitors, and convinced the CEO to invest in training employees on the Six Sigma methods for managing and improving quality. As a consequence, new knowledge was developed internally through collaboration among the R\&D department, the Extrusion and Finishing department, and the Quality Assurance Group. ALPHA is characterized by a collaborative working environment of these three major groups. Besides, the most central nodes have also acted as bridges and gatekeepers between ALPHA and strategic partners, such as the suppliers and the university research centre. For instance, the creation of component-specific knowledge for developing a software tool was driven by the knowledge accumulating nodes.

5.2 What is the impact of managing the knowledge-based linkages on the operational performance?

Knowledge development and sharing along the knowledge-based linkages helped improve the operational performance. The intensive knowledge-based linkages between ALPHA and its competitors made ALPHA realized the benefits of investing in TQM practices and the Six Sigma approach. The introduction of the TQM practices and the Six Sigma approach resulted in two different quality outcomes, highlighted by ALPHA employees:

- Reducing errors and waste, and monitoring components along the extrusion line - Every employee participated in Kanban and Kaizen to improve the quality of the production process, and reduce waste and errors. This whole company collaboration allowed the identification of bottlenecks in the work flow, elimination of errors, and improvements to daily work activities. 
- Changing the approach to problem solving - This was achieved through the adoption of the Six Sigma approach, which is based on the idea of maintaining control over the entire process at every step using statistical analysis tools to reduce variability. As described above, this approach allowed the development of a routine to deal with measurement of viscosity. In fact, in order to create new knowledge by exploiting and exploring the organization's existing capabilities, ALPHA changed its approach to managing and controlling quality. It developed, in collaboration with a university research centre, and patented a virtual simulation tool, which was a significant innovation. This software greatly improved the operational performance of the company, resulting in dramatic reduction in waste on the extrusion line, savings on costs, and increased customer satisfaction.

\section{Conclusions}

This paper has some theoretical and practical implications. It offers insights into the management of knowledge and knowledge relationships with both internal and external members of the organization. It contributes to current debate on the characteristics of organization linkages and how to manage the knowledge transfer process both within a single organization and between organizations. It investigates how knowledge is accumulated, shared, and applied to create organization specific knowledge resources that increase and sustain the organization's competitive advantage.

The practical implications of this study are that it provides insights into the use of SNA to enable managers to get a better understanding of the organization's linkage of resources and capabilities. The knowledge linkage map is important at the inter- and intra-organization levels. Within the organization, it is useful to evaluate how these relationships are maintained and the intensity of knowledge sharing among organizations. SNA provides a visual tool to identify the structure of the knowledge linkage. The monitoring of knowledge flows using the knowledge linkage map is an attempt to better understand the organization-specific conditions under which learning and competitive advantage occur.

There are two recommended future work. First, our hypothesis could be tested on a larger sample. The analysis of multiple case studies using SNA would provide a deeper understanding of the relationship between the knowledge-based linkages at all levels of the supply chain and the integration of knowledge. Second, future research could investigate the dynamic characteristic of knowledge and knowledge flows. Dynamic software exists and would allow ongoing monitoring of dynamics linkages, but requires more complex data analysis. Future research could investigate new ways to collect data in a dynamic context. 


\section{References}

Amin, A. and Cohendet, P. (2005), “Geographies of knowldge formation in firms”, Industry and Innovation, Vol. 12 No. 4, pp. 465-486.

Anand, G., Ward, P.T. and Tatikonda, M. V. (2010), "Role of explicit and tacit knowledge in Six Sigma projects: An empirical examination of differential project success”, Journal of Operations Management, Elsevier B.V., Vol. 28 No. 4, pp. 303-315.

Andersson, U., Forsgren, M. and Holm, U. (2002), “The strategic impact of external networks: subsidiary performance and competence development in the multinational corporation”, Strategic Management Journal, Vol. 23 No. 11, pp. 979-996.

Argote, L., Ingram, P., Levine, J.M. and Moreland, R.L. (2000), “Knowledge transfer in organizations: Learning from the experience of others”, Organizational Behavior and Human Decision Processes, Vol. 82 No. 1, pp. 1-8.

Becker, M. C., and Zirpoli, F. (2003), "Organizing new product development. Knowledge hollowing-out and knowledge integration - the FIAT Autocase", International Journal of Operations and Production Management, Vol. 23 No. 9, pp. 1033-1061.

Bessant, J., 2004. Supply chain learning. In: New, S., Westbrook, R. (Eds.), Understanding Supply Chains. Oxford University Press, New York.

Bessant, J., Kaplinsky, R., and Lamming, R. (2003), "Putting supply chain learning into practice", International Journal of Operations and Production Management, Vol. 23 No. 2, pp. 167-184.

Burns, T., and Stalker, G.M. (1966), The Management of Innovation. 2nd edn, Associated Book Publishers: London.

Carey, S. and Lawson, B. (2011), "Social capital configuration, legal bonds and performance in buyer-supplier relationships”, Journal of Operations Management, Vol. 29 No. 4, pp. 277_ 288.

Cheung, M:, Myers, M.B., Mentzer, J.T. (2010), "Does relationship learning lead to relationship value? A cross-national supply chain investigation", Journal of Operations Management, Vol. 28 No. 6, pp. 472-487.

Choi, T. and Hong, Y. (2002), "Unveiling the structure of supply networks: Case studies in Honda, Acura and Daimler”, Chrysler Journal of Operations Management, Vol. 20 No. 5, pp. 469-493.

Choo, A.S., Linderman, K.W. and Schroeder, R.G. (2007), "Method and context perspectives on learning and knowledge creation in quality management”, Journal of Operations Management, Vol. 25 No. 4, pp. 918-931. 
Clark, K.B. (1989), "Project Scope and Project Performance: The Effect of Parts Strategy and Supplier Involvement on Product Development”, Management Science, JSTOR, Vol. 35 No. 10, pp. 1247-1263.

Desouza, K.C., Chattaraj, A. and Kraft, G. (2003), "Supply chain perspectives to knowledge management: research propositions”, Journal of Knowledge Management, Vol. 7 No. 3, pp. 129-138.

Ding, X.H., Heng, L., and Yongtao, S. (2013), "Are internal knowledge transfer strategies double-edged swords?", Journal of Knowledge Management, Vol. 17 No. 1, pp. 69-86.

Dyer, J.H., and Nobeoka, K. (2000), Creating and managing a high-performance knowledgesharing network: the Toyota case, Strategic Management Journal, Vol. 21 No. 3, pp. 345367.

Eisenhardt, K.M. (1989), “Building Theories from Case Study Research”, The Academy of Management Review, Vol. 14 No. 4, p. 532.

Eisenhardt, K.M. and Graebner, M.E. (2007), “Theory Building from Cases: Opportunities and Challenges”, Academy of Management Journal, Vol. 50 No. 1, pp. 25-32.

Flynn, B.B., Schroeder, R.G. and Sakakibara, S. (1994), “A framework for quality management research and an associated measurement instrument”, Journal of Operations Management, Elsevier, Vol. 11 No. 4, pp. 339-366.

Friedkin, N. (1993), “Structural bases of interpersonal influence in groups: A longitudinal case study”, American Sociological Review, Vol. 58 No. December, pp. 861-872.

Garton, L., Haythornthwaite, C. and Wellman, B. (1997), “Studying on-line social networks”, Journal of Computer-mMediated Communication, Vol. 3 No. 1, pp. 1-36.

Grant, R. (1996), “Toward a knowledge-based theory of the firm”, Strategic management journal, Vol. 17 No. 2, pp. 109-122.

Gunasekaran, a. and Ngai, E.W.T. (2007), "Knowledge management in 21st century manufacturing”, International Journal of Production Research, Vol. 45 No. 11, pp. 23912418.

Hackman, J.R. and Wageman, R. (1995), “Total Quality Management: Empirical, Conceptual, and Practical Issues”, Administrative Science Quarterly, Johnson Graduate School of Management, Cornell University, Vol. 40 No. 2, pp. 309-342.

Hamel, G. (1991), “Competition for competence and inter-partner learning within international strategic alliances”, Strategic management journal, Vol. 12 No. S1, pp. 83-103. 
Hanneman, R.A., \& Riddle, M. (2005). Introduction to social network methods. Riverside, CA: University of California, Riverside (published in digital form (published in digital form at http://faculty.ucr.edu/ hanneman/)

Hansen, M.T., Nohria, N., and Tierney, T. (1999), "What's your strategy fro managing knowledge?” Harvard Business Review, Vol. 77 No. 2, pp. 106-116.

Hult, G.T.M., Ketchen, D.J., Cavusgil, S.T. and Calantone, R.J. (2006), "Knowledge as a strategic resource in supply chains”, Journal of Operations Management, Vol. 24 No. 5, pp. 458-475.

Hult, G.T.M., Ketchen, D.J. and Slater, S.F. (2004), "Information Processing, Knowledge Development, and Strategic Supply Chain Performance.”, Academy of Management Journal, Vol. 47 No. 2, pp. 241-253.

Hurley, R.F., and Hult, G.T.M. (1998), “Innovation, market orientation and organizational learning: an integration and empirical examination”, Journal of Marketing, Vol. 62 No. 3, pp. 42-54.

Ketchen, D.J. and Hult, G.T.M. (2007), "Bridging organization theory and supply chain management: The case of best value supply chains”, Journal of Operations Management, Vol. 25 No. 2, pp. 573-580.

Ketchen,, D.J., Rebarick, W., Hult, G.T.M. and Meyer, D. (2008), “Best value supply chains: A key competitive weapon for the 21st century”, Business Horizons, Vol. 51 No. 3, pp. 235243.

Kilduff, M. and Tsai, W. (2003), Social Networks and Organizations, (Sage,Ed.), London.

Lawson, B., Petersen, K.J., Cousins, P.D. and Handfield, R.B. (2009), “Knowledge sharing in interorganizational product development teams: The effect of formal and informal socialization mechanisms”, Journal of Product Innovation Management, Vol. 26 No. 2, pp. 156-172.

Lee, V.H., Lai-Ying, L., Teck-Soon, H., and Keng-Boon, O. (2013), "Knowledge management: a key determinant in advancing technological innovation?", Journal of Knowledge Management, Vol. 17 No. 6, pp. 848-872.

Leonard-Barton, D. (1995), Wellsprings of knowledge: building and sustaining the sources of innovation, Wellsprings of Knowledge Building and Sustaining the Sources of Innovation, Harvard Business School Press.

Linderman, K., Schroeder, R.G., Zaheer, S., Liedtke, C. and Choo, A.S. (2004), "Integrating quality management practices with knowledge creation processes”, Journal of Operations Management, Vol. 22 No. 6, pp. 589-607. 
Modi, S.B., and Mabert, V.A. (2007), "Supplier development: improving supplier performance through knowledge transfer", Journal of Operations Management, Vol 25 No. 1, pp. 42-64.

Molina, L.M., Lloréns-Montes, J. and Ruiz-Moreno, A. (2007), "Relationship between quality management practices and knowledge transfer”, Journal of Operations Management, Vol. 25 No. 3, pp. 682-701.

Nonaka, T. (1994), “A Dynamic Theory of Organizational Knowledge Creation”, Organization Science, Vol. 5 No. 1, pp. 14-37.

Osterloh, M. and Frey, B. (2000), "Motivation, knowledge transfer, and organizational forms”, Organization science, Vol. 11 No. 5, pp. 538-550.

Polanyi, M. (1962), Personal knowledge, Chicago:IL, University.

Quinn, J. (2000), “Outsourcing innovation: The new engine of growth”, Sloan Management Review, Vol. 41 No. 4, p. 13.

Samuel, K.E., Goury, M.L., Gunasekaran, A., and Spalanzani, A. (2011), "Knowledge management in supply chain: An empirical study from France", The Journal of Strategic Information Systems, Vol. 20 No. 3, pp. 283-306.

Smith, D.J. and Tranfield, D. (2005), “Talented suppliers? Startegic change in the UK aerospace industry and its implications for innovation”, $R \& D$ Management, Vol. 35 No. 1, pp. 37-49.

Tsoukas, H. and Vladimirou, E. (2002), “What is organizational knowledge?”, Journal of Management Studies, Vol. 38 No. 7, pp. 973-993.

Von Hippel, E. and Tyre, M.J. (1995), "How learning by doing is done: problem identification in novel process equipment”, Research Policy, Elsevier, Vol. 24 No. 1, pp. 1-12.

Wadhwa, S., and Saxena, A. (2005), "Knowledge management based supply chain: an evolution perspective", Global Journal of e-Business and Knowledge Management, Vol. 2 No. 2, pp. 13-29.

Wagner, S.M., and Buko, C. (2005), “An empirical investigation of knowledge-sharing in networks”, Journal of Supply Chain Management, Vol. 41 No. 4, pp. 17-31. 


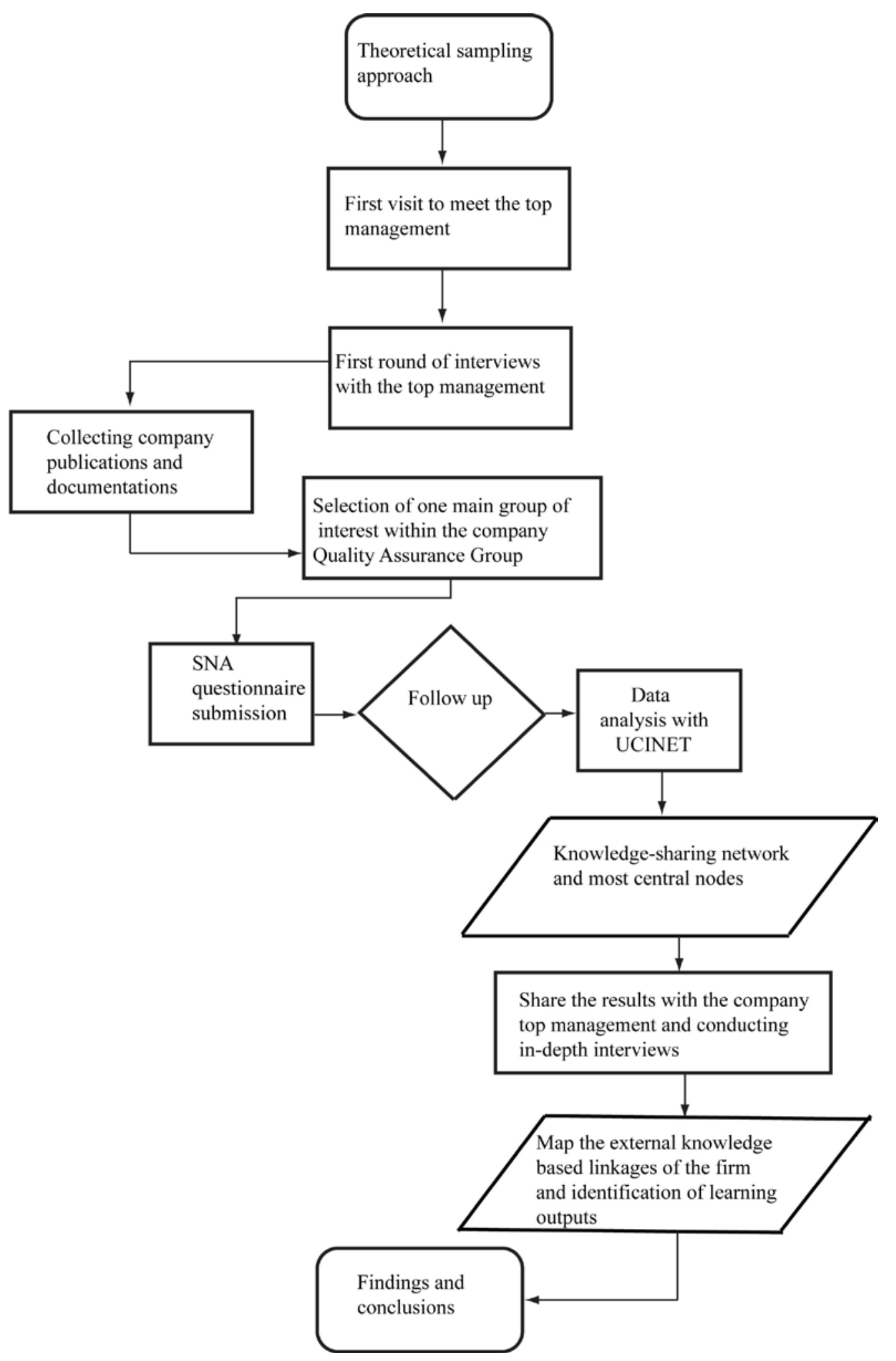

Figure 1. Flow chart of the research methodology 


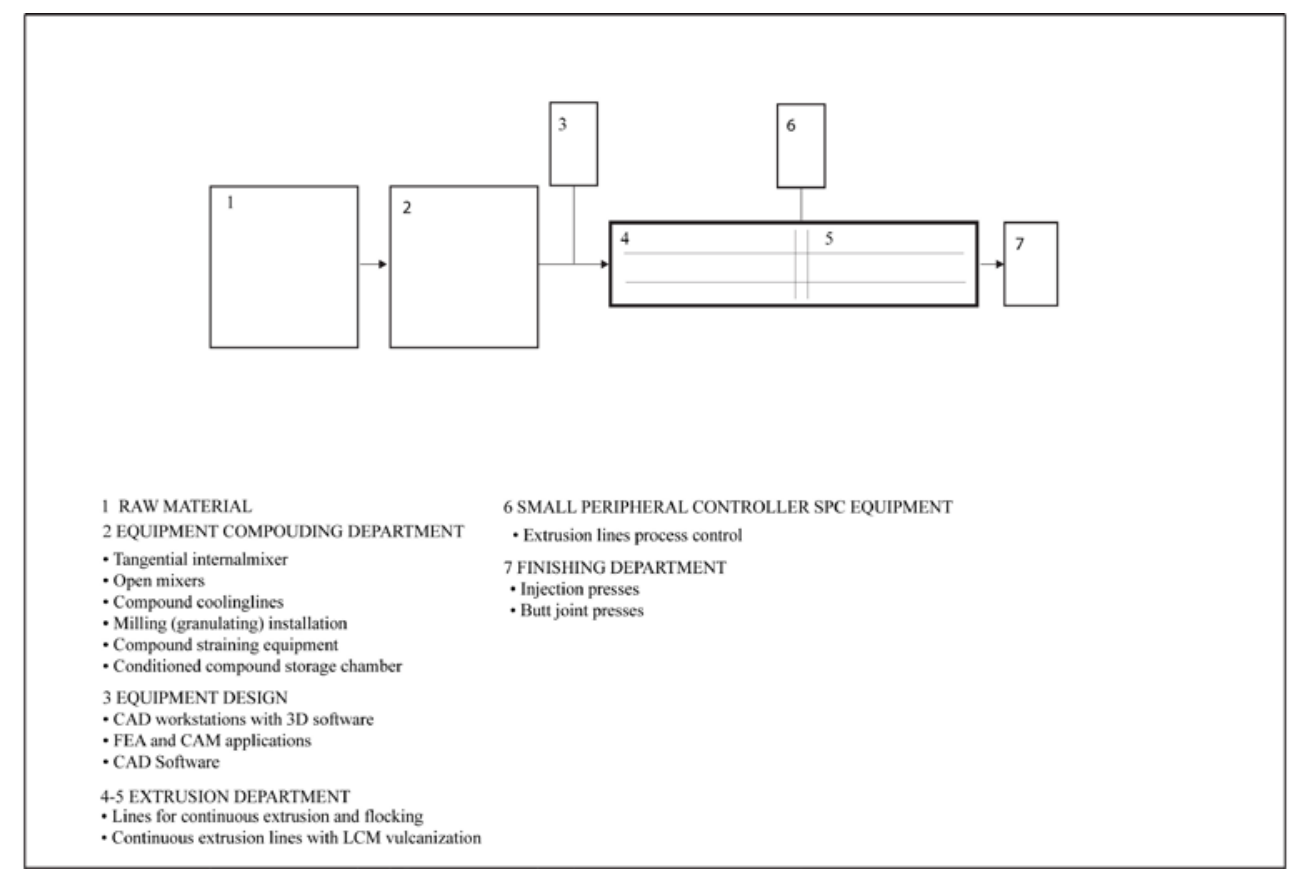

Figure 2. Departmental plan of ALPHA 


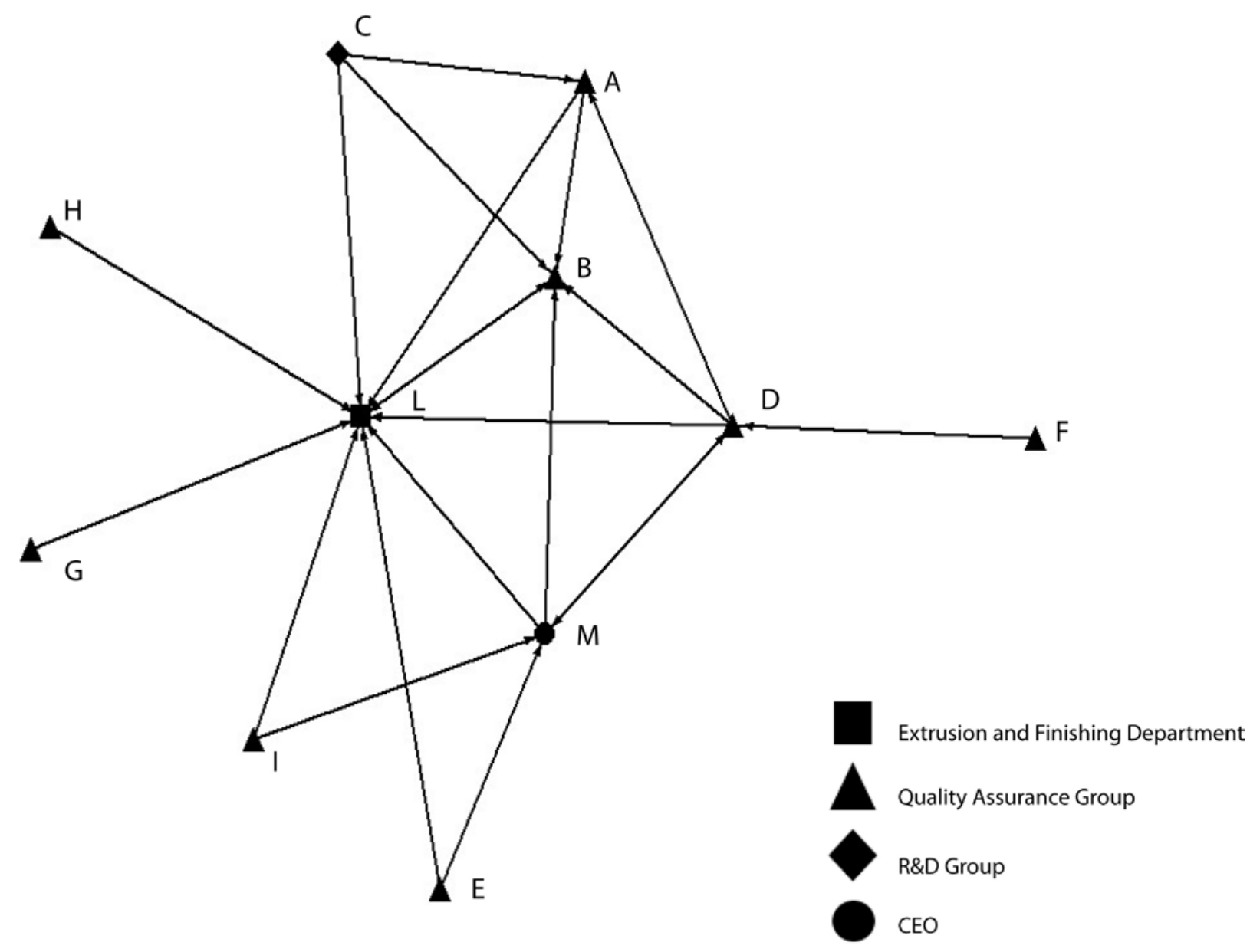

Figure 3. Internal knowledge-based linkages that constitute the structure for knowledge transfer 


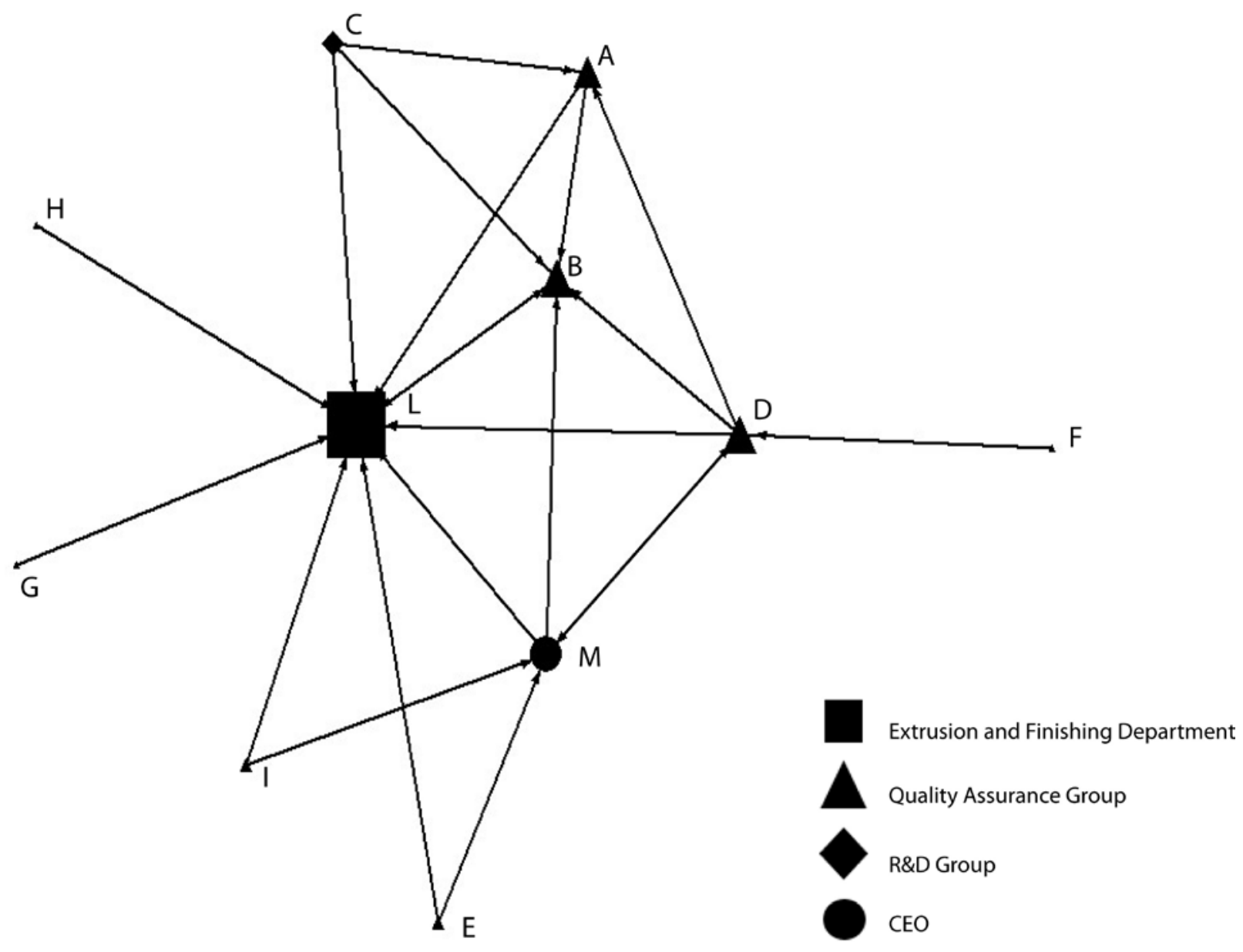

Figure 4. Freeman's degree centrality measures and the knowledge accumulating nodes 


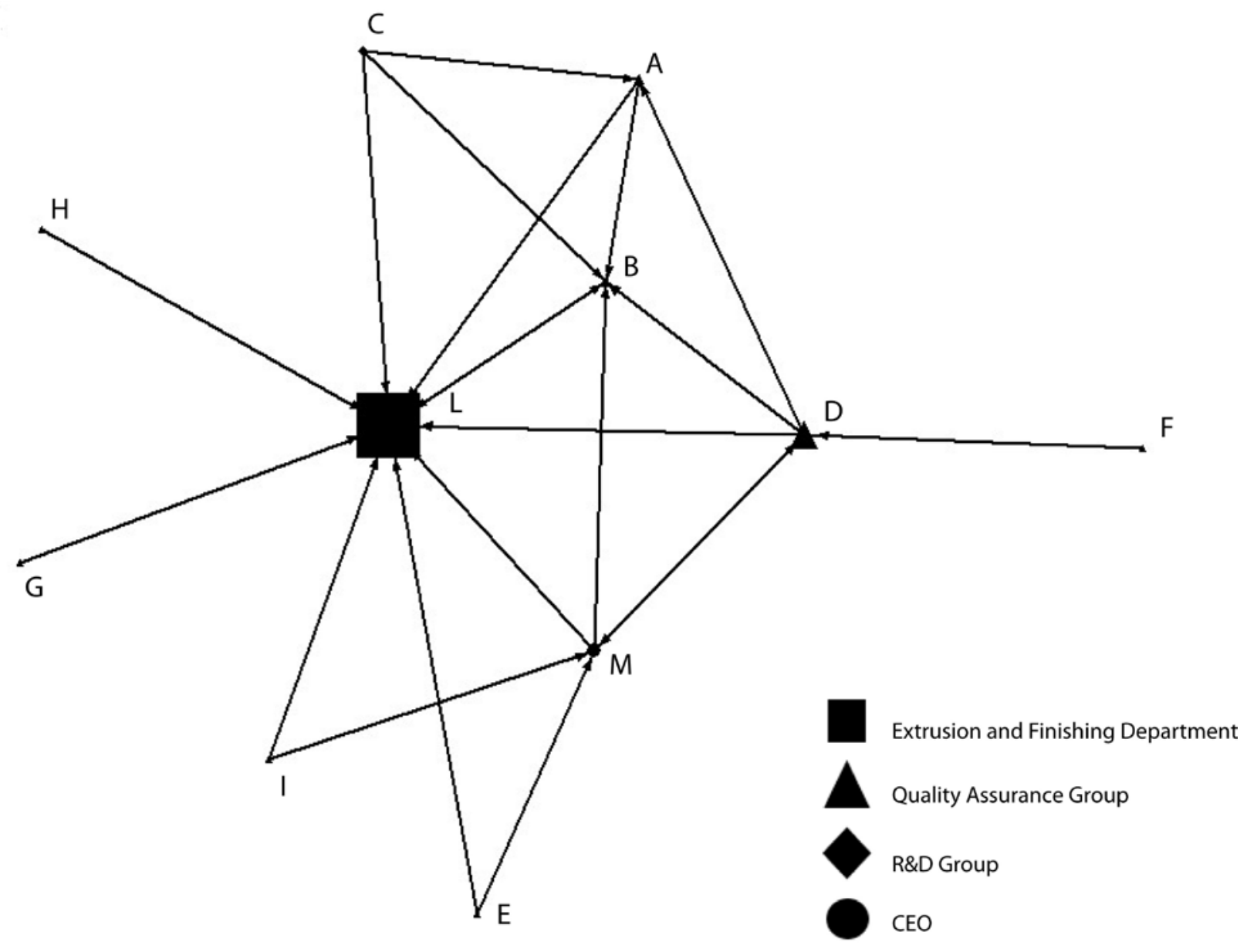

Figure 5. Freeman betweenness centrality 


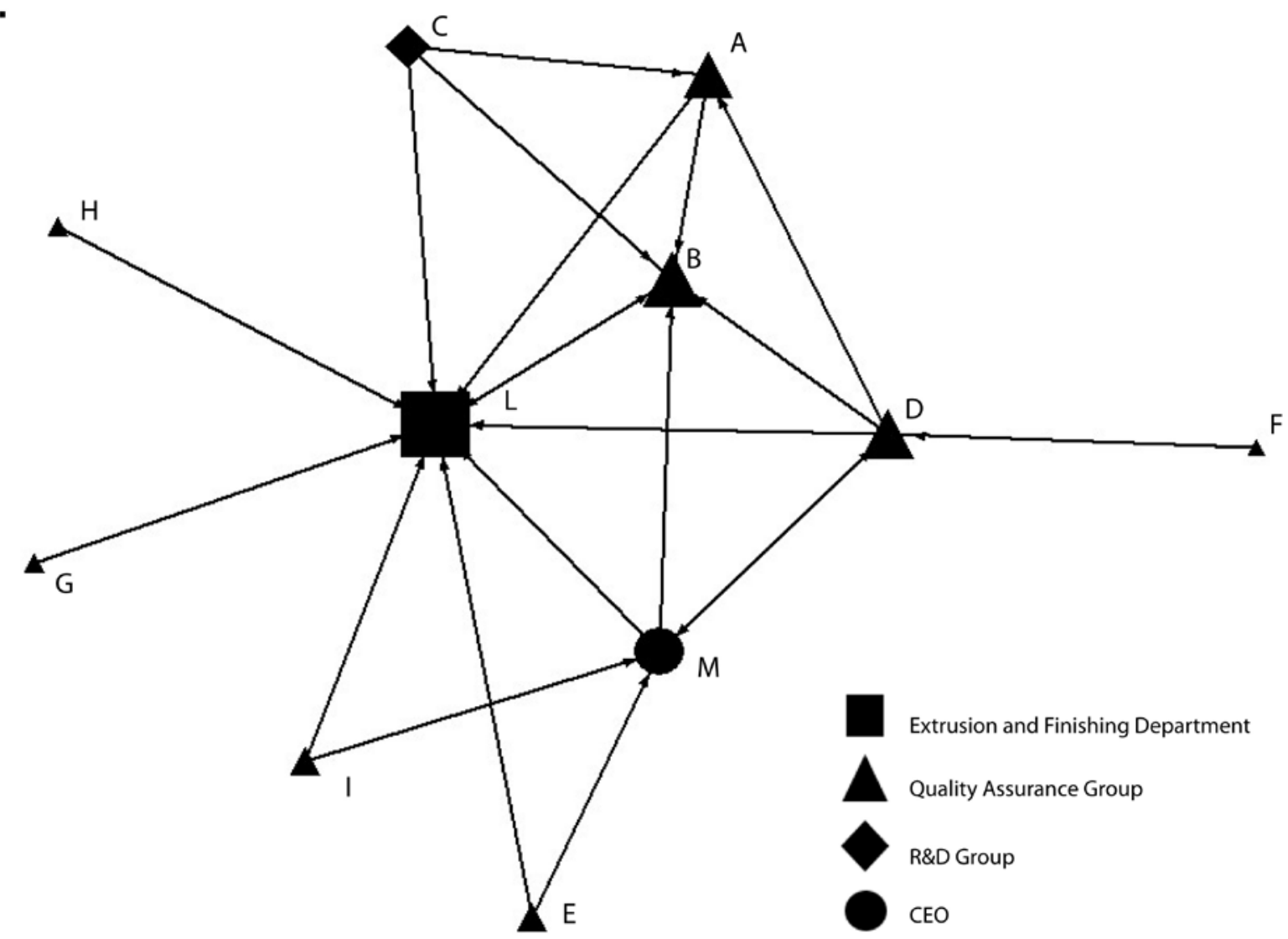

Figure 6. Bonacich Eigenvector centrality 


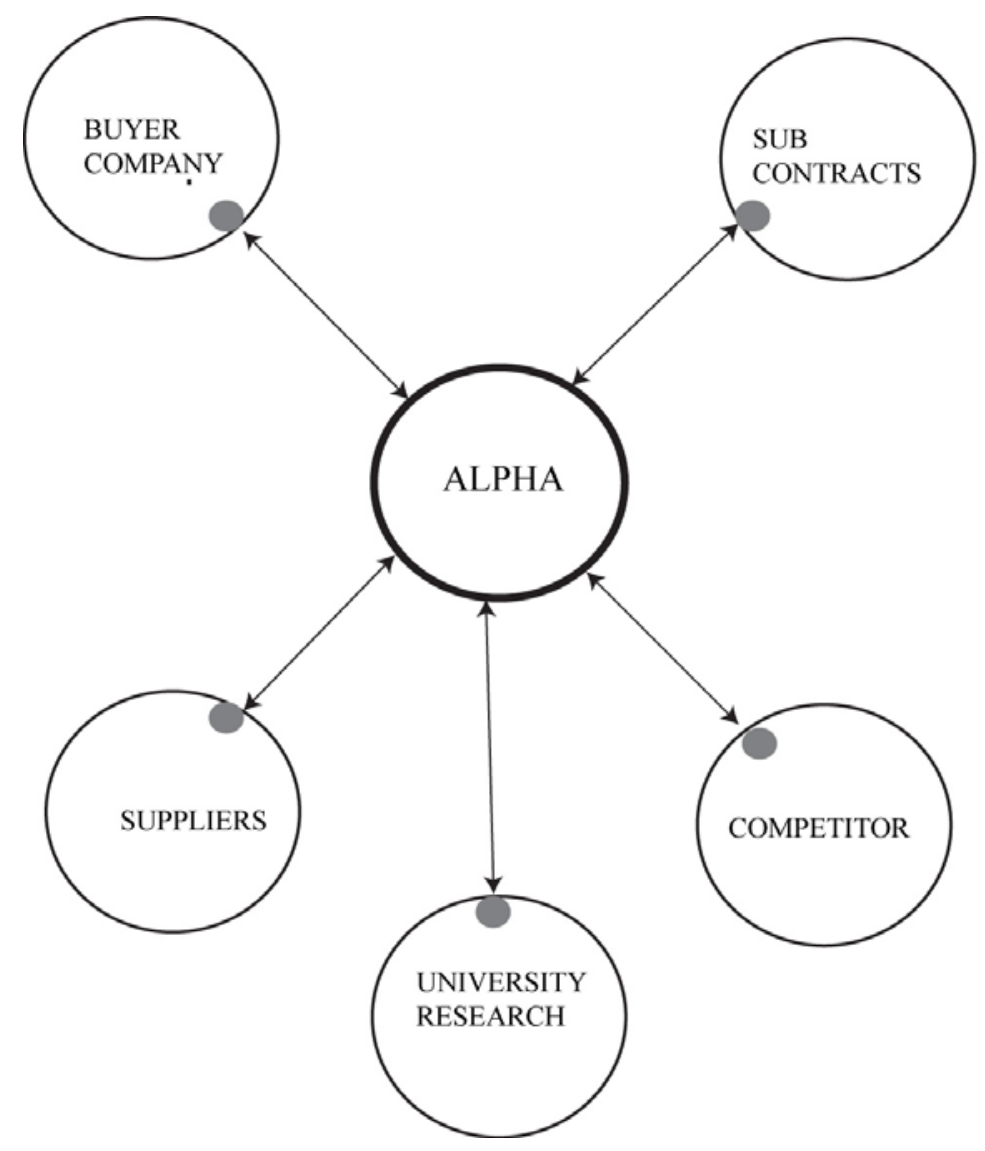

Figure 7. External knowledge-based linkages 


$\begin{array}{rrrrr} & & 1 & 2 & 3 \\ 10 & \text { Nodel } & 9.000 & 90.000 & 0.237 \\ 2 & \text { NodeB } & 5.000 & 50.000 & 0.132 \\ 11 & \text { NodeM } & 5.000 & 50.000 & 0.132 \\ 4 & \text { NodeD } & 5.000 & 50.000 & 0.132 \\ 1 & \text { NodeA } & 4.000 & 40.000 & 0.105 \\ 3 & \text { NodeC } & 3.000 & 30.000 & 0.079 \\ 9 & \text { NodeI } & 2.000 & 20.000 & 0.053 \\ 5 & \text { NodeE } & 2.000 & 20.000 & 0.053 \\ 7 & \text { NodeG } & 1.000 & 10.000 & 0.026 \\ 8 & \text { NodeH } & 1.000 & 10.000 & 0.026 \\ 6 & \text { NodeF } & 1.000 & 10.000 & 0.026\end{array}$

DESCRIPTIVE STATISTICS

$\begin{array}{rrrrr} & & 1 & 2 & 3 \\ & & \text { Degree } & \text { NrmDegree } & \text { Share } \\ 1 & \text { Mean } & 3.455 & 34.545 & 0.091 \\ 2 & \text { Std Dev } & 2.350 & 23.496 & 0.062 \\ 3 & \text { Sum } & 38.000 & 380.000 & 1.000 \\ 4 & \text { Variance } & 5.521 & 552.066 & 0.004 \\ 5 & \text { SSQ } & 192.000 & 19200.000 & 0.133 \\ 6 & \text { MCSSQ } & 60.727 & 6072.727 & 0.042 \\ 7 & \text { Euc Norm } & 13.856 & 138.564 & 0.365 \\ 8 & \text { Minimum } & 1.000 & 10.000 & 0.026 \\ 9 & \text { Maximum } & 9.000 & 90.000 & 0.237 \\ 10 & \text { N of Obs } & 11.000 & 11.000 & 11.000\end{array}$

Network Centralization $=67.78 \%$

Blau Heterogeneity $=13.30 \%$. Normalized $(\mathrm{IQV})=4.63 \%$

Table 1. Degree centrality and network characteristics 


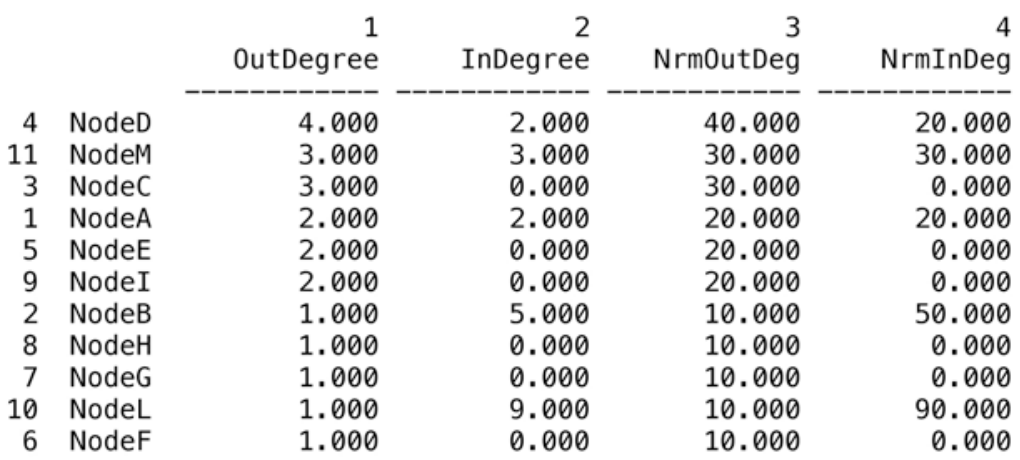

DESCRIPTIVE STATISTICS

\begin{tabular}{rrrrrr} 
& & 1 & 2 & 3 & 4 \\
& & OutDegree & InDegree & Nrm0utDeg & NrmInDeg \\
1 & Mean & 1.909 & 1.909 & 19.091 & 19.091 \\
2 & Std Dev & 0.996 & 2.745 & 9.959 & 27.454 \\
3 & Sum & 21.000 & 21.000 & 210.000 & 210.000 \\
4 & Variance & 0.992 & 7.537 & 99.174 & 753.719 \\
5 & SSQ & 51.000 & 123.000 & 5100.000 & 12300.000 \\
6 & MCSSQ & 10.909 & 82.909 & 1090.909 & 8290.909 \\
7 & Euc Norm & 7.141 & 11.091 & 71.414 & 110.905 \\
8 & Minimum & 1.000 & 0.000 & 10.000 & 0.000 \\
9 & Maximum & 4.000 & 9.000 & 40.000 & 90.000 \\
10 & N of Obs & 11.000 & 11.000 & 11.000 & 11.000 \\
\multicolumn{5}{c}{} \\
twork Centralization (Outdegree) & $=25.556 \%$ & & \\
twork Centralization (Indegree) $=86.667 \%$ & &
\end{tabular}

Table 2. Freeman in-degree and out-degree centrality 
Betweenness nBetweenness

$\begin{array}{rlrl}4 & \text { NodeD } & 7.000 & 7.778 \\ 11 & \text { NodeM } & 5.000 & 5.556 \\ 10 & \text { NodeL } & 3.000 & 3.333 \\ 2 & \text { NodeB } & 0.000 & 0.000 \\ 3 & \text { NodeC } & 0.000 & 0.000 \\ 1 & \text { NodeA } & 0.000 & 0.000 \\ 7 & \text { NodeG } & 0.000 & 0.000 \\ 8 & \text { NodeH } & 0.000 & 0.000 \\ 9 & \text { NodeI } & 0.000 & 0.000 \\ 5 & \text { NodeE } & 0.000 & 0.000 \\ 6 & \text { NodeF } & 0.000 & 0.000\end{array}$

DESCRIPTIVE STATISTICS FOR EACH MEASURE

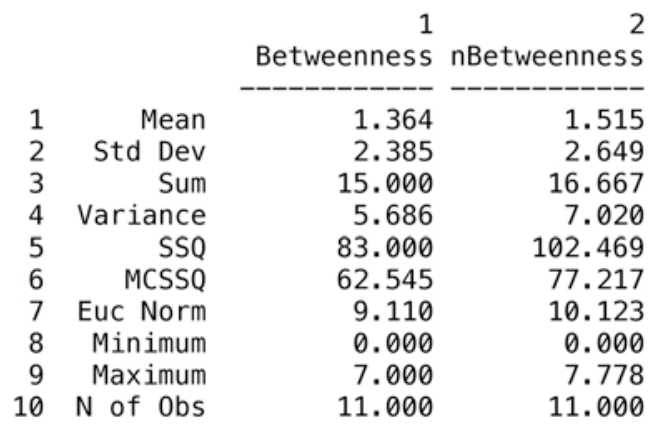

Network Centralization Index $=6.89 \%$

Table 3. Betweeness centrality

Bonacich Eigenvector Centralities

12

Eigenvec nEigenvec

$\begin{array}{ccc}1 \text { NodeA } & 0.341 & 48.293 \\ 2 \text { NodeB } & 0.407 & 57.520 \\ 3 \text { NodeC } & 0.275 & 38.889 \\ 4 \text { NodeD } & 0.372 & 52.616 \\ 5 \text { NodeE } & 0.192 & 27.095 \\ 6 \text { NodeF } & 0.081 & 11.451 \\ 7 \text { NodeG } & 0.112 & 15.860 \\ 8 \text { NodeH } & 0.112 & 15.860 \\ 9 \text { Nodel } & 0.192 & 27.095 \\ 10 \text { NodeL } & 0.515 & 72.876 \\ 11 \text { NodeM } & 0.365 & 51.623\end{array}$

Table 4. Bonacich Eigenvector centrality 


\begin{tabular}{|c|c|c|c|c|}
\hline Name & Role & Department & $\begin{array}{l}\text { Number of } \\
\text { years in the } \\
\text { company }\end{array}$ & $\begin{array}{l}\text { Individual } \\
\text { performance }\end{array}$ \\
\hline A & $\begin{array}{l}\text { Quality Manager and } \\
\text { Master Black Belt }\end{array}$ & $\begin{array}{l}\text { Quality Assurance } \\
\text { Group }\end{array}$ & 10 & $\begin{array}{l}\text { One of the most } \\
\text { knowledgeable } \\
\text { individuals }\end{array}$ \\
\hline B & $\begin{array}{l}\text { Director of the Quality } \\
\text { Assurance Group and } \\
\text { Master Black Belt }\end{array}$ & $\begin{array}{l}\text { Quality Assurance } \\
\text { Group }\end{array}$ & 10 & $\begin{array}{l}\text { Bridge with suppliers } \\
\text { and subcontractors }\end{array}$ \\
\hline $\mathrm{C}$ & $\begin{array}{l}\text { Director of R\&D } \\
\text { Department }\end{array}$ & R\&D Department & 8 & $\begin{array}{l}\text { Bridge with the } \\
\text { Quality Assurance } \\
\text { Group and the } \\
\text { Extrusion and } \\
\text { Finishing Department }\end{array}$ \\
\hline $\mathrm{D}$ & Quality controller & $\begin{array}{l}\text { Quality Assurance } \\
\text { Group }\end{array}$ & 5 & $\begin{array}{l}\text { Gatekeeper between } \\
\text { ALPHA and the } \\
\text { Research Centre }\end{array}$ \\
\hline $\mathrm{E}$ & Quality manager & $\begin{array}{l}\text { Quality Assurance } \\
\text { Group }\end{array}$ & 6 & \\
\hline $\mathrm{F}$ & Senior quality controller & $\begin{array}{l}\text { Quality Assurance } \\
\text { Group }\end{array}$ & 8 & \\
\hline G & Employee & $\begin{array}{l}\text { Quality Assurance } \\
\text { Group }\end{array}$ & 10 & \\
\hline$\overline{\mathrm{H}}$ & Employee & $\begin{array}{l}\text { Quality Assurance } \\
\text { Group }\end{array}$ & 7 & \\
\hline $\mathrm{I}$ & Employee & $\begin{array}{l}\text { Quality Assurance } \\
\text { Group }\end{array}$ & 5 & \\
\hline $\mathrm{L}$ & $\begin{array}{l}\text { Director of Extrusion } \\
\text { and Finishing } \\
\text { Department and Master } \\
\text { Black Belt }\end{array}$ & $\begin{array}{l}\text { Extrusion and } \\
\text { Finishing } \\
\text { Department }\end{array}$ & 10 & $\begin{array}{l}\text { Broker of access to } \\
\text { different sources of } \\
\text { knowledge and } \\
\text { bridge with suppliers } \\
\text { and subcontractors }\end{array}$ \\
\hline $\mathrm{M}$ & CEO & Top Management & 16 & $\begin{array}{l}\text { Bridge between } \\
\text { ALPHA and the } \\
\text { university research } \\
\text { centre }\end{array}$ \\
\hline
\end{tabular}

Table 5. Description of ALPHA's internal members 


\begin{tabular}{|c|c|c|c|c|}
\hline Partner & $\begin{array}{l}\text { Knowledge- } \\
\text { based linkages }\end{array}$ & $\begin{array}{l}\text { Length of } \\
\text { knowledge- } \\
\text { based } \\
\text { linkage } \\
\end{array}$ & $\begin{array}{l}\text { Output/Learning } \\
\text { outcome }\end{array}$ & $\begin{array}{l}\text { Operational } \\
\text { Performance }\end{array}$ \\
\hline Buyer company & $\begin{array}{l}\text { Knowledge } \\
\text { sharing about } \\
\text { improvement of } \\
\text { product quality }\end{array}$ & $\begin{array}{l}\text { On-going } \\
\text { relationship }\end{array}$ & $\begin{array}{l}\text { Acquisition of the } \\
\text { awareness about } \\
\text { improvement of } \\
\text { product quality in } \\
\text { the market scenario }\end{array}$ & $\begin{array}{l}\text { Strict control of } \\
\text { measures and } \\
\text { parameters to } \\
\text { produce highly } \\
\text { precise products } \\
\text { with respect to } \\
\text { the buyer's } \\
\text { specifications }\end{array}$ \\
\hline Competitors & $\begin{array}{l}\text { Knowledge } \\
\text { sharing about } \\
\text { TQM practices }\end{array}$ & 2 years & $\begin{array}{l}\text { Acquisition of } \\
\text { knowledge about } \\
\text { Six Sigma } \\
\text { implementation }\end{array}$ & $\begin{array}{l}\text { Improved process } \\
\text { control and } \\
\text { product quality; } \\
\text { Reduced wastes }\end{array}$ \\
\hline $\begin{array}{l}\text { University } \\
\text { research centre }\end{array}$ & $\begin{array}{l}\text { Knowledge } \\
\text { exchange for the } \\
\text { software } \\
\text { development to } \\
\text { monitor the } \\
\text { entire production } \\
\text { process }\end{array}$ & 3 years & $\begin{array}{l}\text { Development of the } \\
\text { algorithm and the } \\
\text { patented software } \\
\text { tool }\end{array}$ & $\begin{array}{l}\text { Increased new } \\
\text { product } \\
\text { development } \\
\text { performance; } \\
\text { Increased } \\
\text { flexibility and } \\
\text { customization; } \\
\text { Reduced costs }\end{array}$ \\
\hline Suppliers & $\begin{array}{l}\text { Knowledge } \\
\text { sharing about the } \\
\text { best TQM } \\
\text { practices }\end{array}$ & $\begin{array}{l}\text { On-going } \\
\text { relationship }\end{array}$ & $\begin{array}{l}\text { The suppliers } \\
\text { introducing the } \\
\text { same TQM } \\
\text { practices in their } \\
\text { daily activities } \\
\text { became "talented } \\
\text { suppliers" }\end{array}$ & $\begin{array}{l}\text { Reduced } \\
\text { inventory level } \\
\text { and increased } \\
\text { speed in } \\
\text { answering } \\
\text { requests; } \\
\text { Increased level of } \\
\text { customer } \\
\text { satisfaction }\end{array}$ \\
\hline Subcontractors & $\begin{array}{l}\text { Knowledge } \\
\text { sharing about the } \\
\text { best TQM } \\
\text { practices }\end{array}$ & $\begin{array}{l}\text { On-going } \\
\text { relationship }\end{array}$ & $\begin{array}{l}\text { They grew up } \\
\text { together with } \\
\text { ALPHA from micro } \\
\text { enterprises to small } \\
\text { enterprises }\end{array}$ & $\begin{array}{l}\text { Reduced } \\
\text { inventory level } \\
\text { and increased } \\
\text { speed in } \\
\text { answering } \\
\text { requests; } \\
\text { Increased level of } \\
\text { customer } \\
\text { satisfaction }\end{array}$ \\
\hline
\end{tabular}

Table 6. Learning outcomes and impacts of external knowledge-based linkages 


\section{University Library}

\section{- M M I E E R VA A gateway to Melbourne's research publications}

Minerva Access is the Institutional Repository of The University of Melbourne

Author/s:

Marra, M;Ho, W;Ka Man Lee, C

Title:

Managing supply chain knowledge-based linkages for improving operational performance

Date:

2016

Citation:

Marra, M., Ho, W. \& Ka Man Lee, C. (2016). Managing supply chain knowledge-based linkages for improving operational performance. Knowledge Management Research and Practice, 14 (3), pp.256-269. https://doi.org/10.1057/kmrp.2014.28.

Persistent Link:

http://hdl.handle.net/11343/118644 